\title{
National Games for Local Gains: \\ Legislative Activity, Party Organization and Candidate Selection
}

\author{
Mihail Chiru \\ Universsity Louvain-la-Neuve
}

Sergiu Gherghina

University of Glasgow

\begin{abstract}
Conventional research on political careers has emphasized the use of local offices as a springboard for national careers. However, movements in the reverse direction can also happen when local offices are available and attractive for national level politicians. This article argues and tests how various types of legislative behavior and party strategy influence the likelihood that national legislators run in local elections. The analysis focuses on Romania and uses an original dataset compiled for the 2016 local elections. Our findings show that legislators with a rich record of parliamentary activity will continue at national level, while those who do constituency work, and those who can help their parties more locally, move to local politics.
\end{abstract}

Keywords: candidate selection, parliamentary activity, party organization, local elections.

\section{Introduction}

Political careers link different offices both horizontally, between institutions, and vertically, between territorial levels of government. Earlier studies seeking to explain why movement happens vertically indicate the existence of three possibilities (Schlesinger 1966; Scarrow 1997; Borchert 2003; 2011; Stolz 2003; 2010; Dodeigne 2014). The first is the existence of alternative arenas, in which national and sub-national political careers are clearly separated. Second come integrated arenas where movement is both centripetal and centrifugal. The third is characterized by hierarchical movements towards one arena, i.e. national or sub-national. Regarding the latter, extensive research has explained that the shift between the sub-national 
and national levels of government has usually taken the shape of ambitious politicians using local or regional offices as a springboard for their national careers. Socialization in local politics influences MPs' behavior and their relations with the two principals: the party and the voters. Members of Parliament (MPs) who have held office in local politics are more likely to attract a personal vote but they also tend to behave more independently in the legislature (Shugart et al. 2005; Tavits 2010) and to engage more in constituency service (Freeman \& Richardson 1996; Norris 1997). Nevertheless, movement is possible in the opposite direction too, since politicians are rational actors who seek to maximize their power and ability to achieve political goals, which may sometimes be achieved by moving away from national politics (Francis \& Kenny 2000, p.2). Legislators are sometimes inclined to seek political office at the local level to pursue their personal or partisan goals (Samuels 2003). This happens especially when local level offices are available, accessible, and attractive to legislators (Borchert 2011).

Consistent with the latter line of enquiry, our article seeks to explain the selection of national legislators as candidates in local elections, the necessary step for a career shift from national to local office. It does so by comparing and contrasting the explanatory power of two scenarios regarding political careers and candidacy decisions. On the one hand, we test the extent to which legislators engaged in constituency-oriented parliamentary activities have an increased likelihood of pursuing attractive local offices. On the other hand, we follow a party organizational approach and argue that the decision to run in local elections could be the result of both individual incentives and party strategy. The innovative character of the article lies in its attempt to bridge two bodies of literature - career patterns and candidate selection - and to reach beyond the conclusions of earlier empirical analyses of MPs' candidacies in local elections. Our article seeks to illustrate that this process is driven both by individual and organizational rationales that are not visible at first glance.

The analysis draws on an original dataset, which matches the parliamentary activities and profiles of the Members of the lower Chamber of the sixth Romanian Parliament (20122016) with candidate data from the 2016 local elections. Our multivariate quantitative analysis distinguishes between two elected offices that may be pursued at local level (mayor and county councilor). There are several reasons that make Romania an appropriate setting to test for 
these effects: local elections include two levels of government (i.e. community and county level) - these are elections for different offices that allow politicians to pursue various political goals; the electoral system used in local elections is a mixture between candidate- and partycentered approaches; and there is no mandate accumulation, so parliamentarians must choose between careers at the national or local level.

The remainder of this article is structured as follows. The next section presents the theoretical underpinnings and key arguments behind the hypothesized effects. We then briefly describe the context of local elections in Romania. The fourth section details the research design, with an emphasis on the variable operationalization and data. Next, we discuss the results of our multivariate analyses, while in the conclusion we summarize the key findings and their implications.

\section{Candidates' assets and partisan needs}

Politicians' career paths are influenced by several factors, which can be grouped into two broad categories: individual and institutional (Schlesinger 1966; Samuels 2003; Borchert 2011; Edinger \& Jahr 2016; Sieberer \& Muller 2017). At individual level, the candidates' political ambition, activities in office and strategic choices guide their political careers. However, individual choices are constrained by formal rules, informal procedures and the settings in which these careers develop. Accordingly, a series of institutional opportunities shape career change. Our theoretical model is based on the neo-institutionalist approach and uses the professionalization of elites and the notion of parties as gate-keepers as two non-exclusive determinants of career patterns. Political career choices provide insights about the quality of pay-offs received or foreseen by legislators for moving to other political levels. We argue that MPs can either work to stay in parliament by building a strong individual profile linked to that office or move to local politics if their priorities are constituency-oriented and their party needs them to strengthen its territorial presence.

\section{Professionalization in and for Parliament}


Our point of departure is the idea that political careers are shaped by the political opportunity structures (Schlesinger 1966; Borchert 2011). In more concrete terms, opportunity structures can be narrowed down to the availability, accessibility and attractiveness of offices. Previous research has emphasized that the professionalization of politicians in elected office is one important driver of their national career pattern. The experience and expertise acquired in office increase the likelihood that an MP will continue in Parliament, as professionalization enhances the triple A-s discussed above. Thus, incumbent legislators have access to a variety of resources and office perks (Borchert 2003). Apart from salary and staff, other resources such as visibility and various means of communication with voters are available. Their activity in the national legislature provides politicians with access to free publicity through media channels. Press conferences, interviews aimed at revealing their policy initiatives to the public, and even conflict situations, in which representatives engage with other officials, put them in the spotlight, and ensure broad coverage of their activities (Herrnson 2004; Stonecash 2008). In turn, MPs' visibility can play an instrumental role in elections by either adding a personal dimension to organizational attachment in the case of partisan voters or by winning over undecided citizens (Däubler et al. 2016). Incumbent legislators have countless opportunities to convey messages about the quality of their activity. They can play the cards of experience, expertise or political authority. Thus, even without remembering specific initiatives, voters are exposed to the idea of the hard-working legislator and tend to reward them (Cotta \& Best 2007; Däubler et al. 2016).

These advantages often give incumbent legislators an upper hand in electoral competition. Politicians who wish to continue their political career in representative bodies depend on the support of both the public and of their party. The two are tied to each other and legislators who try to climb the ladder of public office face relevant party dependence (Muller 2000). The professionalization and visibility of MPs also make them attractive to parties. One reason for this is that MPs with experience and legislative expertise generate lower costs for the parties: they know how the institution works and can be efficient without requiring an adaptation period. Experienced parliamentarians tend to be more loyal to the party at roll-call votes compared to newcomers (Keena \& Knight-Finley 2018). Equally importantly, political 
parties could maintain a core group of experienced legislators because this can bring them electoral gains (Gherghina 2014) and help them avoid the negative effects that high levels of turnover have on policy work (Andersen \& Thorson 1984).

The attractiveness of the office is higher for experienced MPs with a long career in the legislature. Those who are active in the legislature and hold high office, i.e. a mega-seat, are likely to find Parliament more attractive as an arena than backbenchers (Chiru et al. 2013). Based on these arguments, we expect that MPs holding high office in the legislature (H1), having longer experience in Parliament $(\mathrm{H} 2)$ and undertaking intensive parliamentary activity (H3) would have a lower probability of being nominated in local elections than other MPs.

\section{Party strategies}

Political parties are gatekeepers to elected office and can influence the opportunity structure. The previous section showed how parties are directly interested in maintaining MPs with a certain profile in the legislature. The following section outlines the rationales behind parties filling sub-national offices with MPs featuring other characteristics. One relevant component is constituency service, which reflects a socialization of legislators in their own sub-national arenas, an avenue through which they can they develop and enhance the local party (Stolz 2010). From a policy perspective, local offices can also be attractive for implementing local policies (Brouard et al. 2013) and thus represent a job that better suits the policy goals of constituency-oriented MPs.

In their relation to voters, MPs try to signal responsiveness. Given their position and resources, MPs may promote specific local agendas and claim credit for the delivery of public goods in the constituency. Casework or pork barrel have different potentials regarding the number of constituents that can be reached but they are both basic mechanisms through which legislators maintain and eventually enhance a personal vote (Cain et al. 1987). Parliamentarians engage in constituency service with the aim of increasing their chances of a favorable electoral result (Mayhew 1974). Empirical evidence shows that the time invested by MPs in constituency work finds reward in their re-nomination for a new legislative seat (Papp \& Russo 2018). With the partial exception of the US (Gelman and King 1990), such efforts do not provide a cushion 
against the party's electoral unpopularity at national level. Individual members cannot succeed if the party fails to achieve parliamentary representation. The game is somewhat safer when played at the local level, where MPs can benefit from the results of their constituency work and are less affected by the national electoral fortunes of the party. In addition, when exposed to cross-pressures between local and national party interests, MPs are likely to do whatever suits their career best (Muller 2000). Those with intensive constituency work will have support at the local level if they decide to continue there their political career.

Electoral systems and the type of party competition can influence both career paths (Borchert \& Zeiss 2003; Samuels \& Shugart 2010) and the ways in which constituency work is valued by parties. Different electoral system logics push parties to select candidates with different profiles. Thus, in proportional representation (PR) closed list systems, the likelihood of parties nominating loyal party soldiers as candidates is greater than in single member district (SMD)-based elections, where the candidate's visibility and appeal are a priority. Constituency service is rewarded differently: in list PR systems it is much less valued compared to SMD-based elections in which intensive constituency service sometimes generates higher vote shares (Chiru 2018). Changes in electoral rules can also affect the opportunity structure. For example, a reduction in legislature size increases intra-party competition for parliamentary office (higher demand) and induces greater incentives for some politicians to shift to sub-national careers.

Political parties have territorial strongholds, units in which the party is electorally stronger compared to the national average level of support. The existence of strongholds triggers two types of party behaviors: one that follows the core voter model applicable in parties' own strongholds (Cox \& McCubbins 1986) and another that follows the swing voter model (Lindbeck \& Weibull 1987) in areas where the party is weaker, including the strongholds of other parties. Since vote maximization is a core goal of most political parties, these are motivated by both short-term concerns (i.e. expanding their electoral support) and long-term considerations (i.e. maintaining and stabilizing their loyal supporters over time). Without a solid basis of support, a vote maximization strategy is risky, as electoral volatility can destabilize the party. To enhance a solid basis of stable electoral preferences, political parties are likely to target and distribute benefits primarily to their core voters (Cox \& McCubbins 1986). Such 
benefits range from clientelism and patronage to the constituency service provided by MPs. Outside their electoral strongholds, political parties may seek vote maximization in forms that are best described by the swing voter model. Political parties and politicians do not provide benefits to their loyal supporters as they are likely to receive their votes anyway, and instead target voters whose support may be gained through incentives (Dahlberg \& Johansson 2002). The nomination in local elections of MPs known for their legislative work or with high name recognition can serve this purpose. Such a strategy can lead to an efficient and effective vote mobilization and could compensate for local politicians' lack of popularity. At the same time, such a candidacy is likely to face little opposition from the party on the ground, given the circumstances.

One of the ways in which political parties can accommodate their need for survival on the political scene with the needs of MPs' personal careers is through party discipline. The latter reduces the "excesses" of MPs (Jones \& Hudson 1998) and increases party loyalty among legislators (Kam 2009). Through a gradual process of norm internalization, MPs end up sharing a conformist view of what makes a behavior appropriate (Andeweg \& Thomassen 2011). This behavior reflects what the political party wishes to achieve in public office (in terms of policies) and how it tries to present itself to the outside world as a homogenous, non-divided political actor. Party unity enhances both the value of the party label for voters and the ability of party leaders to negotiate governmental office and policies. For these reasons, dissenters are not easily maintained in office by political parties. Parties might try to get rid of rebels by sending them to ply their trade in local politics. In this way, parties would benefit simultaneously from both the dissenters' popularity in the local contests and from an increased level of party loyalty in the national legislature. Since dissent at roll call votes in Parliament might be motivated by responsiveness to local interests, parties make a different career path available to such MPs. Dissent in the legislature does not make the MPs less competent, but illustrates that they are more inclined to follow their own views or the views of their constituents. Such behavior can be more beneficial in local politics - or at least less detrimental than in the national parliament. Given all these arguments, we expect MPs who put a lot of effort into constituency work (H4), 
MPs from constituencies where their party underperformed in previous elections (H5) and MPs who dissent more $(\mathrm{H} 6)$ to be more likely to run in local elections.

\section{Controls}

In addition to the hypothesized effects, we control for experience in local politics, electoral security (safe seats), party switching and age. We expect MPs who have held local office in the past to be more likely to run in local elections because they might have higher name recognition and good relations with local selectorates. This variable is also useful for moderating a potential endogeneity problem, i.e. the idea that parliamentary behavior is driven by the desire to run in local elections. While, because of data availability, we could not control for past local candidatures that could rule out this possibility, the local politics experience variable is a strong proxy for interest in a career at local level.

Safe seats could generate ambivalent effects. On the one hand, those MPs who obtained a higher vote share could be more popular politicians and could choose to use their personal vote to gain office at a local level. On the other hand, MPs who were elected with a small margin or mainly due to the party vote might try to obtain local office knowing that their re-election to parliament is uncertain at best and improbable at worst. Party switching is a common phenomenon in Romanian legislative politics and earlier research found that MPs often switch for strategic reasons, i.e. joining a more popular party (Gherghina 2016; Klein 2016). We control for it because political parties may want to test the capacity of these newcomers to win votes. In addition, parties may ask these MPs to do some campaign work to increase their chances of being accepted by the local party branch. Age could also have an impact on the likelihood of MPs to run in local elections since it could be argued that older legislators are less likely to leave their parliamentary seat.

\section{The 2016 local elections in Romania}

Local elections in Romania are organized for three offices: mayor, local councilor (alderman) and county councilor. Out of these, we select the mayoral and county councilor elections, mainly because they involve much more power and responsibility than the local council 
positions. Mayors are local government leaders of villages, communes (conglomerates of villages), towns and cities; they have executive power and work together with the local council. The country isdivided into 42 counties: 41 county councils with between 31 and 37 councilors, proportional to the size of the population, and the council for the capital city, Bucharest, which has 55 members. In total, there were 3,186 mayor positions and 1,436 county councilor seats contested in these elections. The elections take place simultaneously, for a four-year term in office; voters receive three different ballots and the electoral systems used to decide the winners differ. Mayors are elected using the First Past the Post electoral system, while county council elections use closed list Proportional Representation. The leadership of county and local party organizations nominates most of the candidates for these elections, while the final lists (particularly for higher level positions) are decided with the involvement of the national party leaders.

The two main actors in the Romanian party system dominated the June 2016 local elections. The Social Democratic Party (PSD) won more than 53\% of the mayoral offices and around $44 \%$ of the county councilor positions. ${ }^{1}$ The National Liberal Party (PNL) won around $34 \%$ of the mayoral positions and $36 \%$ of the county councilor seats. The Hungarian ethnic party, the Democratic Alliance of Hungarians in Romania (UMDR) won 6\% of the mayoral seats and almost $7 \%$ of the county councilor positions. The last parliamentary party that obtained more than $5 \%$ of the vote was The Alliance of Liberals and Democrats from Romania (ALDE), which gained $5.5 \%$ of the county councilor seats but only $2 \%$ of the mayoral positions. 55 deputies ran for mayors and 60 were nominated on county council candidate lists.

In Romania, politicians are not allowed to cumulate local and national office. If elected, MPs have to renounce their seat in order to take up the new position. In the end, 56 deputies were elected: 12 as mayor and 44 as county councilors. Only 20 of them resigned to take up their local mandates: all MPs who were elected mayors and eight of the MPs who had won seats on county councils. The rest of the 36 county council seats gained by deputies remained in the hands of these parties and were assigned to the candidates next in line on the lists. ${ }^{2}$

\footnotetext{
${ }^{1}$ The figures also include the mandates won by PSD in some local alliances with a fringe party, UNPR.

${ }^{2}$ Although our dependent variable measures being a candidate or not in local elections and not the actual move to local politics, running for a local office is the first, necessary step for such a career shift. Only $36 \%$ of the MPs who
} 
Between 2012 and 2016, the electoral rules changed at national level, with two direct consequences for local level elections. First, the voting system changed from a mixed member proportional system - in which all MPs are elected from SMDs - to closed-list PR. This change, as mentioned in the previous section, could influence the profile of the parliamentarians nominated for office at national and sub-national levels and the rewards of constituency service. Second, the legislature size decreased by approximately one fifth and this was likely to lead to a higher competition within each party for parliamentary seats.

Local offices are appealing for national politicians in Romania for several reasons. One of them is the political power and intra-party influence that a mayor of a large city or a county council president has in comparison to a parliamentary backbencher. Beyond the power of deciding on considerable budgets, county council presidents are also key actors in their parties, because of their role in vote mobilization. In line with these perceptions, two parliamentary surveys conducted in 2003 and 2010 have shown that around 10\% of Romanian MPs consider a local executive office more important than a legislative mandate (Chiru et al. 2013, p.39). ${ }^{3}$ In particular, the position of a county council president is the most attractive since it implies deciding on the allocation of substantial levels of public funds and public contracts.

Previous research (Stefan 2016) has indeed shown that, every term, a few dozen MPs take leave from Parliament to run for sub-national office. Moreover, the share of those who resign from Parliament to take up elected local office is not at all small, indicating that such a step is often perceived as career advancement and not demotion. Thus, of the 127 MPs of the largest party, PSD, who resigned from Parliament between 1990 and 2004, 59 (46.4\%) did so in order to occupy an office at local or county level (Stefan 2016: 151). The same research has shown that - as in 2016 - Romanian MPs were also much more likely to resign in previous

\footnotetext{
were elected went into local politics, but this obscures the fact that all MPs who won mayoral positions or became presidents of county councils actually resigned from Parliament and took up these seats. The above finding also does not say anything about the likelihood of career shift of those who were not elected (57 MPs). It is in fact reasonable to think the latter would have happily shifted to local politics given the comparatively worse electoral fortunes of their parties.

${ }^{3}$ The question asked: "how important is it for you to be a Member of Parliament in comparison with other public offices?" The options were: "Being an MP is the most important office", "I would prefer an executive position within the local administration", "I would prefer an executive position within the central administration, in the government" and "They are all equally important".
} 
terms when elected to a top local office (mayor, president or vice-president of county council) rather than just to a simple county councilor or alderman role (Stefan 2016: 154).

A second reason regarding the appeal of local office is specific to the 2016 local elections and the lower number of seats in the future national legislature. The 2015 electoral reform re-introduced closed list PR in national legislative elections and reduced the number of MPs to 448 seats. ${ }^{4}$ Facing the prospect of a smaller parliament, some MPs may have been inclined to try their luck in the local elections. However, this does not imply endogeneity regarding the MPs' legislative behavior, since the Parliament only adopted the electoral reform regarding national parliamentary elections 10 months before the 2016 local elections. This decreases considerably the likelihood that the MPs' legislative behavior was driven by their calculations regarding their diminished chances of getting re-elected and allegedly better prospects of local office.

It is also worth mentioning that none of the MPs running for local office admitted that uncertainty regarding legislative re-election was a concern, while virtually all of those interviewed by the national media emphasized the attractiveness of these sub-national offices (particularly the positions of mayor or county council president) and that they would enable them to do more for their communities than they could achieve within Parliament. A minority of these MPs also explained their candidature as a task received from the party while maintaining they were happy to put their visibility to good use (Digi 24 2016; Badea 2016).

\section{Research design}

We focus on elections for two types of offices at the local level: mayor and county councilor. Therefore, both dependent variables are dichotomous and record whether a member of the 2012-2016 Chamber of Deputies ran in the local elections for the above-mentioned positions (0 for not running, 1 for running). The Chamber of Deputies (lower Chamber) is considered the main decision chamber of the Romanian Parliament. Our analysis includes the 368 MPs from the Chamber of Deputies that could have participated in the elections, i.e. those who were alive

\footnotetext{
${ }^{4}$ In 2012, Romania used a mixed member proportional system in which the allocation of a considerable number of overhang seats to the winners resulted in a record number of MPs: 570 . None of these figures include the 18 reserved seats competed for by organizations of national minorities.
} 
and not imprisoned at the start of the local elections campaign. ${ }^{5}$ We excluded the deputies of the national minorities. MPs ran in local elections in 40 counties. The only two counties where no deputy ran were Harghita and Covasna, which are inhabited by a vast majority of ethnic Hungarians. The information regarding the MPs running in local elections were retrieved from the Central Electoral Bureau.

High office in the legislature (H1) is conceptualized as an MP holding a parliamentary office. This is measured as a dichotomous variable that distinguishes between MPs without parliamentary office (0) and MPs who are committee chairs or deputy chairs, or had a leadership position at the parliamentary party group or Chamber level (1). For parliamentary experience $(\mathrm{H} 2)$ we use seniority, measured on an ordinal scale. A case is coded 0 if the MP was elected to Parliament for the first time in 2012, 1 when the MP had previous parliamentary experience at the time of the 2012 elections but only 4 years or less, 2 if at the time of the 2012 elections the MP had served more than one term in parliament but no more than 8 years, and 3 if at the time of the 2012 elections the MP had served more than two terms in parliament. Given the high turnover in the Romanian Parliament (Chiru and Popescu 2017), an ordinal measurement of parliamentary experience is a more appropriate choice than a continuous variable, because it produces more balanced and meaningful categories.

We use the number of parliamentary speeches and interventions in debates of individual MPs as a proxy for intense involvement in parliamentary activities (H3). We selected these two types because they require elaboration and in-depth activity on a certain issue. This variable is an interval-ratio measured as the logged number of speeches. For constituency work $(\mathrm{H} 4)$ we use the number of parliamentary questions and interpellations submitted by the MPs on issues from their constituency. ${ }^{6}$ This is also an interval-ratio variable, which records the logged number of questions and interpellations. We use the natural logarithm for variables at $\mathrm{H} 3$ and $\mathrm{H}^{7}$ because it is likely that the marginal effect of an additional unit of each of these activities is not constant but rather decreases with the number of questions already submitted

\footnotetext{
${ }^{5}$ A total of 394 MPs were elected to the Chamber of Deputies in 2012, excluding the national minorities' reserved seats.

6 The questions were coded automatically using the GeoNames database to match the text of the questions and interpellations with geographical names from the county where the MP's district was located.

${ }^{7} 0.5$ was added to all question, bill and speech counts since it is impossible to take the logarithm of zero.
} 
and speeches made (Däubler et al. 2016, p.429). The data regarding the individual parliamentary activity of MPs was downloaded from the parliamentary monitoring tool, Parlament Transparent (Transparent Parliament), and covers the entire period from the beginning of the term in December 2012 until late May 2016. ${ }^{8}$

Electoral stronghold $(\mathrm{H} 5)$ is a count measure that captures the vote percentage at county level gained by the candidates of each party at the 2014 presidential election. That is the most recent previous election held at the national level. Although the president is obliged to give up partisan affiliation after winning office, political parties play a key role in election campaigns. They back candidates with resources, organize their campaigns and, quite often, presidential candidates are the main leaders of political parties. Dissent $(\mathrm{H} 6)$ is measured as the percentage of final roll-call votes in which the MP voted differently from her party between the beginning of the term in office (December 2012) until the moment when votes were no longer publicly available (February 2016).

Party switching is a dichotomous variable coded 0 for the MPs who did not change party affiliation during the analyzed period and 1 where MPs left the party under whose banner they were elected. Safe seats refer to the 2012 parliamentary elections: this variable is measured on a reverted scale based on the difference between the $50 \%+1$ implicit threshold and the percentage of votes received by the MP at the time - i.e. the extra percentage of votes the MP would have needed to win the single member district directly, with negative numbers meaning surplus votes. We reversed the scale so that a higher value implies a higher likelihood of winning the seat directly. Whereas electoral stronghold measures the party strength at county level, this variable captures the individual electoral marginality or the personal vote potential of the MP.

The local level experience is another ordinal variable, coded 0 if the MP has never held local office, 1 when the MP has served in such an office for 4 years or less, 2 if the legislator served more than 4 years but a maximum of 8 years, and 3 for all longer records. Age is a count

\footnotetext{
${ }^{8}$ An exception is represented by the roll-call vote data, which covers only the December 2012 - February 2016 period. This is so because, following a scandal regarding the results of an electronic vote, individual votes were no longer published by the official website of the Chamber of Deputiesuntil spring 2017; the data were scraped by Parlament Transparent.
} 
variable that captures the MP's age in years at the time of the 2016 local elections. Table 1 below summarizes the descriptive statistics for all variables.

Table 1 about here

\section{Horses for courses: MPs in mayor and local council elections}

Table 2 presents the findings of the logistic regression models ran on the sample of 368 MPs. ${ }^{9}$ The two sets of regressions evaluate separately the likelihood of being nominated in the mayoral and in the county council elections. In interpreting the results, we will focus more on the effect size because it provides the substantive significance of the quantitative analysis (Harlow et al. 2016). Statistical significance will also be reported only to illustrate the probability that the observed difference is not due to chance. Since we work with the entire universe of cases - all the members of the Chamber of Deputies in the 2012-2016 term in office - and not with statistical samples, the statistical significance is somewhat of secondary importance; it is nevertheless useful when seeking to generalize to the broader theoretical population of future MPs in Romania. The models are run first without the controls and then with controls.

When explaining which MPs are more likely to run for mayor, there is a strong negative effect related to the MP's position, experience and activity in the legislature. The empirical evidence provides support for $\mathrm{H} 1-\mathrm{H} 3$ and indicates that MPs with such a prominent profile are considerably less likely to run for mayor compared with their fellow MPs, who do not occupy a parliamentary office, have less legislative experience and have limited activity. As expected, parliamentary seniority is not associated with a propensity to move into local politics: legislators who served for three terms or more are $13 \%$ less likely to run for a mayoral position than their newcomer colleagues.

\footnotetext{
${ }^{9}$ The findings are not affected by multicollinearity: the variance inflation factors were small for all variables, with the highest VIF (2.02) being registered for the party switching dummy. The Online Appendix presents the results of the regression models ran on samples that exclude outliers with respect to the three parliamentary activity variables. The magnitude of the effects is extremely similar to those presented in Table 2 below.
} 
We observe that there is a positive effect associated with asking constituency questions: MPs who raise local issues in their questions and interpellations have a higher likelihood to be nominated in mayoral elections. Running margins showed that there is an $18 \%$ increase in the probability of running when we compare the MPs who asked no local questions with those who were the most active in this respect. This can be interpreted as evidence that the parties attempt to capitalize on the constituency service efforts of their MPs in their candidate selection decisions.

\section{Table 2 about here}

There is a weak but statistically significant (at the 0.01 level) effect of the electoral strongholds, which points in the hypothesized direction. MPs are slightly more likely to run in constituencies in which their party underperformed in the previous national elections compared to strongholds. Thus, for the highest difference in vote share (0 vs. 69\%) the decrease in the probability of running amounts to $20 \%$. Further, MPs who dissent more often are slightly more likely to run for mayoral positions than those who are loyal party soldiers: a $10 \%$ increase in the average level of dissent at final roll-call votes brings a $10 \%$ higher likelihood of participating in these elections. This effect indicates that, even though the occurrence of dissent is fairly limited, it is not accidental and it has career consequences.

The empirical support for the hypothesized effects $(\mathrm{H} 1-\mathrm{H} 6)$ holds when introducing the control variables. The goodness-of-fit of the model improves only marginally with the four controls, while the statistical significance of some determinants (parliamentary seniority and roll-call dissent) is lost. Nevertheless, and quite important for this analysis, the effect direction and size remain similar. The effects of the control variables are not particularly strong. Party hopping MPs are 7\% more likely to run for mayor compared to the MPs who stayed put. MPs who were elected comfortably (i.e. winning more than $50 \%$ of the votes in the SMDs) are $4 \%$ more likely to run in mayoral elections. In addition, MPs who held local level offices for more than 8 years are only $8 \%$ more likely to run for mayor than their colleagues with no local level 
experience. Last but not least, MPs in their 30 s are $17 \%$ more likely to participate in these elections than those who are 60 .

The first model on county council elections tells a slightly different story. The empirical evidence goes against the first two hypotheses and shows that MPs who held a parliamentary office and those with legislative experience are more likely to run for councilor positions. However, the difference in participation probabilities are only marginally higher: less than $5 \%$ for MPs who hold parliamentary office as compared to backbenchers, and around 3\% when comparing the most senior legislators with newcomers. This attractiveness may be related to the advantages provided by such an office in terms of influence and actual responsibility at the county level. A county councilor has less responsibility regarding policy implementation than a mayor and is more involved in deliberating and bargaining over the decisions. An alternative explanation is that parties have nominated reputable and experienced MPs to top their county council lists only to profit electorally from their visibility and without the actual intent of moving these cadres into local politics.

Less active MPs, and those investing more efforts into constituency service, are more likely to run for county councils, both effects corroborating the expected empirical relations (H3 and H4). Those legislators most active in asking constituency questions have a $13 \%$ higher probability of participating in county council elections compared with colleagues who never asked such questions. When the same comparison is made with respect to parliamentary speeches, more active MPs are $8 \%$ less likely to run in local elections. The empirical evidence supports H5, with MPs being more likely to be nominated as candidates in constituencies that are not electoral strongholds of the party. The highest difference in vote share at the previous elections ( 0 vs. $69 \%$ ) produces a decrease in the probability of running of approximately $29 \%$.

The empirical evidence for $\mathrm{H} 6$ is quite strong, statistically significant at the 0.01 level and goes against the hypothesized effect: loyal MPs are more likely to run in the county council elections. There is $16 \%$ decrease in the likelihood of participating in these elections when we compare MPs who always to the party line with those who rebelled in $10 \%$ of the votes. This seems to corroborate the idea that parties chose a different strategy than for mayoral 
elections: nominating loyal party soldiers, who would accept running in these contests even if they were not necessarily keen to move into local politics.

The model with controls produces virtually identical effects for the hypothesized relationships. With respect to controls, they have comparable effects and point in similar directions to those in the model for mayoral elections. For example, MPs who switched parties are $7 \%$ more likely to run for county council positions. ${ }^{10} \mathrm{MPs}$ who have held local level offices for more than 8 years are $18 \%$ more likely to be nominated in these elections than their colleagues who have no local level experience.

\section{Conclusion}

This article analyzed the drivers of MPs' participation in the 2016 local elections in Romania. Our theoretical framework focused on two types of explanations for the change in career path: MPs' activities and party strategies. The general findings suggest that the MPs who devote a lot of effort to legislative work are less likely to run in local elections, while those oriented towards constituency work are more likely to change arenas. This effect was partially augmented by the electoral reform at national level that introduced the important change from a mixed-member system in 2012 to a closed-list PR system in 2016. Under the new rules, constituency work had a greater chance of being rewarded in local elections.

MPs were also more likely to run in constituencies that were not electoral strongholds of their parties, thereby seeking to make a contribution to boosting party support. There are relevant differences between the effects found for mayoral and county council elections. MPs who hold high office in the legislature and who have a longer record of experience as legislators are less likely to run for mayor. The dissenters are more likely to run because a lack of loyalty towards their party in Parliament might indicate responsiveness to local interests. For county council elections, frontbenchers, experienced and loyal MPs are more likely to run. This is partly because their role as councilor would mirror their activity as parliamentarians, and partly because they are less likely to be forced to take up these positions - i.e. their failure not to do

\footnotetext{
${ }^{10}$ We also controlled for how many times a legislator changed party affiliation during the term, but this factor did not make any difference.
} 
so is less likely to attract public outrage compared to a similar situation regarding the mayoral election.

The implications of our study move beyond the single case study presented here. The findings are generalizable to institutional settings in which national party organizations hold some control over the MPs' career paths and where local politics is not a formal and strong regional alternative to national politics, as happens in many federal countries. The normatively concerning practice of MPs winning sub-national seats and not taking them up is likely to happen in other newly democratized countries, where the local and national media fail to offer adequate coverage and civil society organizations are too weak or disinterested and cannot mobilize citizens to sanction the respective parties and politicians.

At a theoretical level, the framework we use suggests a combination of legislative professionalization, individual legislator utility maximization and party strategies, which-most of the time - have been treated separately in the literature. The study bridges two bodies of literature - on parliamentary behavior and party organization. In doing so, we analyzed the determinants of movement from the national to the local layer of politics while integrating information regarding the involvement and parliamentary activism of the level hopping politicians, an aspect disregarded by earlier research. We illustrated this connection in a unitary country, in which some local level offices are attractive for politicians. The findings that parties make a strategic choice regarding which MPs should run in such elections and potentially move into local politics - depending on their degree of involvement and types of activities in the legislature - is an important contribution to the literature on career movement. As such, these are factors that could be included in further analyses seeking to understand the reasons behind political career shifts.

On empirical grounds, the results confirm earlier research according to which the more professionalized an institution, the more attractive it will become for politicians (Stoltz 2003). The Romanian case indicates that, in a professionalizing parliament, MPs who invest resources in legislative activities continue their work in that office, while those who are oriented towards their constituency and can be useful for sub-national party needs will seek local office. Additionally, MPs might perceive the executive position of mayor and the legislative role of 
county counselor in a distinctive light. The movement from the national to the local level does not follow similar trends for the two offices, but appears driven by the tasks that are to be fulfilled. This indicates generally strategic and rational behavior from both the MPs and their political parties.

Future studies could analyze whether the nomination strategies of the sort described here can indeed be an efficient vote winning strategy, either by comparing actual parties' vote shares in local election races where they nominated MPs with those where they did not, or by using experimental designs. A more qualitative approach would also be welcome to bring the MPs' own motivations and incentives to play this game into the picture. 


\section{List of References:}

Andersen, K. \& Thorson, S.J., 1984. Congressional Turnover and the Election of Women. Western Political Quarterly, 37(1), pp.143-156.

Andeweg, R.B. \& Thomassen, J., 2011. Pathways to party unity: Sanctions, loyalty, homogeneity and division of labour in the Dutch parliament. Party Politics, 17(5), pp.655-672.

Borchert, J., 2011. Individual Ambition and Institutional Opportunity: A Conceptual Approach to Political Careers in Multi-level Systems. Regional \& Federal Studies, 21(2), pp.117-140.

Borchert, J., 2003. Professional Politicians: Towards a Comparative Perspective. In J. Borchert \& J. Zeiss, eds. The Political Class in Advanced Democracies. Oxford: Oxford University Press, pp. 1-25.

Borchert, J. \& Zeiss, J., 2003. The Political Class in Advanced Democracies: A Comparative Handbook, Cambridge: Cambridge University Press.

Brouard, S. et al., 2013. Why do French MPs Focus More on Constituency Work than on Parliamentary Work? The Journal of Legislative Studies, 19(2), pp.141-159.

Cain, B., Ferejohn, J. \& Fiorina, M., 1987. The Personal Vote: Constituency Service and Electoral Independence, Cambridge: Cambridge University Press.

Chiru, M. 2018. The Electoral Value of Constituency-Oriented Parliamentary Questions in Hungary and Romania. Parliamentary Affairs, (online first).

Chiru, M., Gherghina, S. \& Stefan, L., 2013. Standing for Reelection under Different Rules. Problems of Post-Communism, 60(5), pp.34-44.

Cotta, M. \& Best, H. eds., 2007. Democratic Representation in Europe. Diversity, Change, and Convergence, Oxford: Oxford University Press.

Cox, G.W. \& McCubbins, M.D., 1986. Electoral Politics as a Redistributive Game. Journal of Politics, 48(3), pp.370-389.

Dahlberg, M. \& Johansson, E., 2002. On the Vote-Purchasing Behavior of Incumbent Governments. American Political Science Review, 96(1), pp.27-40.

Däubler, T., Bräuninger, T. \& Brunner, M., 2016. Is Personal Vote-Seeking Behavior Effective? Legislative Studies Quarterly, 41(2), pp.419-444.

Dodeigne, J., 2014. (Re-)Assessing Career Patterns in Multi-Level Systems: Insights from 
Wallonia in Belgium. Regional \& Federal Studies, 24(2), pp.151-171.

Edinger, M. \& Jahr, S. eds., 2016. Political careers in Europe: Career patterns in multi-level systems, Baden-Baden: Nomos.

Francis, W.L. \& Kenny, L.W. eds., 2000. Up the Political Ladder: Career Paths in U.S. Politics, Thousand Oaks: Sage Publications.

Freeman, P.K. \& Richardson, L.E.J., 1996. Explaining Variation in Casework among State Legislators. Legislative Studies Quarterly, 21(1), pp.41-56.

Gherghina, S., 2014. Party Organization and Electoral Volatility in Central and Eastern Europe: Enhancing Voter Loyalty, London: Routledge.

Gherghina, S., 2016. Rewarding the "traitors"? Legislative defection and re-election in Romania. Party Politics, 22(4), pp.490-500.

Harlow, L.L., Mulaik, S.A. \& Steiger, J.H. eds., 2016. What If There Were No Significance Tests? Classic ed., London and New York: Routledge.

Herrnson, P., 2004. Congressional Elections: Campaigning at Home and in Washington, Washington DC: CQ Press.

Jones, P. \& Hudson, J., 1998. The Role of Political Parties: An Analysis Based on Transaction Costs. Public Choice, 94(1-2), pp.175-189.

Kam, C.J., 2009. Party Discipline and Parliamentary Politics, Cambridge: Cambridge University Press.

Keena, A. \& Knight-Finley, M., 2018. Governed by Experience: Political Careers and Party Loyalty in the Senate. Congress \& the Presidency, 45(1), pp.20-40.

Klein, E., 2016. Electoral Rules and Party Switching: How Legislators Prioritize Their Goals. Legislative Studies Quarterly, 41(3), pp.715-738.

Lindbeck, A. \& Weibull, J.W., 1987. Balanced Budget Redistribution and the Outcome of Political Competition. Public Choice, 52(3), pp.273-297.

Mayhew, D.R., 1974. The Electoral Connection, New Haven: Yale University Press.

Muller, W.C., 2000. Political parties in parliamentary democracies: Making delegation and accountability work. European Journal of Political Research, 37(3), pp.309-333.

Norris, P., 1997. The puzzle of constituency service. The Journal of Legislative Studies, 3(2), 
pp.29-49.

Papp, Z. \& Russo, F., 2018. Parliamentary Work, Re-Selection and Re-Election: In Search of the Accountability Link. Parliamentary Affairs, (online first).

Samuels, D., 2003. Ambition, Federalism, and Legislative Politics in Brazil, Cambridge: Cambridge University Press.

Samuels, D.J. \& Shugart, M.S., 2010. Presidents, Parties, and Prime Ministers. How the Separation of Powers Affects Party Organization and Behavior, Cambridge: Cambridge University Press.

Scarrow, S.E., 1997. Political Career Paths and the European Parliament. Legislative Studies Quarterly, 22(2), p.253.

Schlesinger, J.A., 1966. Ambition and Politics: Political Careers in the United States, Chicago: Rand MacNally.

Shugart, M.S., Valdini, M.E. \& Suominen, K., 2005. Looking for Locals: Voter Information Demands and Personal Vote-Earning Attributes of Legislators under Proportional Representation. American Journal of Political Science, 49(2), pp.437-449.

Sieberer, U. \& Muller, W.C., 2017. Aiming higher: The consequences of progressive ambition among MPs in European Parliaments. European Political Science Review, 9(1), pp.27-50.

Stolz, K., 2003. Moving Up, Moving Down: Political Careers Across Territorial Levels. European Journal of Political Research, 42(2), pp.223-248.

Stolz, K., 2010. Towards a Regional Political Class? Professional Politicians and Regional Institutions in Catalonia and Scotland, Manchester: Manchester University Press.

Stonecash, J.M., 2008. Reassessing the Incumbency Effect, Cambridge: Cambridge University Press.

Tavits, M., 2010. Effect of Local Ties On Electoral Success and Parliamentary Behaviour: The Case of Estonia. Party Politics, 16(2), pp.216-235.

Online resources: 
DIGI 24. 2016. https://www.digi24.ro/special/dosare/alegeri-locale-2016/dau-parlamentul-peadministratia-locala-150-de-parlamentari-si-au-depus-candidatura-la-alegerile-locale522685, last accessed March 3, 2018

Parlament Transparent, https://parlament.openpolitics.ro/, last accessed February 20, 2017

Website of the Central Electoral Bureau, http://www.2016bec.ro/rezultate-finale-10-06-2016/, last accessed February 20, 2017 
Table 1: Descriptive statistics of dependent variables and covariates $(N=368)$

\begin{tabular}{l|l|cccc}
\hline Variable type & Variables & Mean & Std. dev & Min. & Max. \\
\hline DVs & Mayor candidate & 0.15 & 0.36 & 0 & 1 \\
& County council candidate & 0.16 & 0.37 & 0 & 1 \\
& Local elections candidate & 0.31 & 0.46 & 0 & 1 \\
\hline IVs & Party vote at 2014 elections & 30.71 & 18.39 & 0 & 69.87 \\
& Log. Local PQs & 1.66 & 1.64 & -0.69 & 6.53 \\
& Log. Speeches & 3.48 & 1.49 & -0.69 & 9.43 \\
& Roll call dissent (\%) & 3.07 & 4.29 & 0 & 29.18 \\
& Roll call presence (\%) & 74.80 & 18.32 & 5.98 & 100 \\
& Parliamentary office & 0.40 & 0.49 & 0 & 1 \\
& Parliamentary seniority & 0.77 & 0.98 & 0 & 3 \\
\hline Controls & Local politics experience & 0.94 & 1.03 & 0 & 3 \\
& Safe seats 2012 & 0.56 & 0.23 & 0 & 1 \\
& Party switcher & 0.41 & 0.49 & 0 & 1 \\
& Age & 50.19 & 9.48 & 28 & 70 \\
\hline
\end{tabular}


Table 2: Determinants of MP candidacies in the 2016 local elections (logistic regressions)

\begin{tabular}{l|c|c|c|c}
\hline & $\begin{array}{c}\text { Mayor } \\
\text { (I) }\end{array}$ & $\begin{array}{c}\text { Mayor } \\
\text { (II) }\end{array}$ & $\begin{array}{c}\text { County } \\
\text { council (I) }\end{array}$ & $\begin{array}{c}\text { County } \\
\text { council (II) }\end{array}$ \\
\hline Parliamentary & 0.81 & 0.78 & 1.45 & 1.56 \\
office & $(0.24)$ & $(0.23)$ & $(0.52)$ & $(0.53)$ \\
Parliamentary & $0.59^{* *}$ & 0.69 & 1.09 & 1.19 \\
seniority & $(0.15)$ & $(0.19)$ & $(0.15)$ & $(0.22)$ \\
Speeches & 0.88 & 0.91 & 0.93 & 0.97 \\
& $(0.15)$ & $(0.17)$ & $(0.13)$ & $(0.12)$ \\
Local PQs & $1.27^{*}$ & $1.23^{*}$ & 1.15 & 1.07 \\
& $(0.16)$ & $(0.15)$ & $(0.13)$ & $(0.11)$ \\
Electoral & $0.97^{* * *}$ & $0.97^{* *}$ & $0.96^{* * *}$ & $0.97^{* * *}$ \\
strongholds & $(0.01)$ & $(0.01)$ & $(0.01)$ & $(0.01)$ \\
Roll call dissent & $1.07^{* *}$ & 1.03 & $0.85^{* * *}$ & $0.83^{* * *}$ \\
& $(0.03)$ & $(0.03)$ & $(0.04)$ & $(0.04)$ \\
\hline Party switching & & 1.81 & & 1.76 \\
& & $(0.80)$ & & $(0.65)$ \\
Safe seats & & 1.38 & & 1.34 \\
& & $(1.15)$ & & $(0.93)$ \\
Local politics & & 1.26 & & $1.55^{* *}$ \\
experience & & $(0.18)$ & & $(0.27)$ \\
Age & & $0.95^{* * *}$ & & 0.99 \\
& & $(0.02)$ & & $(0.02)$ \\
\hline $\mathrm{N}$ & 368 & 368 & 368 \\
McFadden's $\mathrm{R}^{2}$ & 0.14 & 0.17 & 0.09 & 0.11 \\
\hline $\mathrm{N}$ & & 368 &
\end{tabular}

Notes: Significance at $* p<0.10, * * p<0.05, * * * p<0.01$

Cell entries are odds ratios, robust standard errors clustered by county in brackets. 